\title{
The Public Discourse of American Animated Films in China
}

\author{
Xiao $\mathrm{Hu}^{1,2} \&$ Xiaoyu Dong ${ }^{1}$ \\ ${ }^{1}$ School of Journalism and Communication, Southwest University, Beibei, Chongqing, China \\ ${ }^{2}$ School of Culture and Communication, Chongqing University of Arts and Sciences, Yong Chuan, Chongqing, \\ China \\ Correspondence: Xiao Hu, School of Journalism and Communication, Southwest University, Beibei, Chongqing, \\ China. Tel: 86-139-9628-0289. E-mail: hxo_0@hotmail.com
}

Received: August 11, 2013 Accepted: August 19, 2014 Online Published: September 29, 2014

doi:10.5539/ass.v10n19p258 URL: http://dx.doi.org/10.5539/ass.v10n19p258

\begin{abstract}
America animated films process experienced cultural integration process when imported into China. It will be analyzed the ways America animated films interpretation for public discourse, and Chinese reading of the American animated film works. Finally, it will be discussed the reasons America animated films won the favor of China children and parents.
\end{abstract}

Keywords: America animated films, audiences, public discourse, Chinese language reading

At the beginning of $1990 \mathrm{~s}$, American animated films launched a series classic animated films with the integration of the world's cultural resources, participating in and changing the public discourse space in movies. For example, "Aladdin" from Arabia myth, and so on.

American animated films have been succeed in utilizing foreign cultural themes, converting and transmitting. Hua Mu Lan is the first success American animated film which adapted from Chinese ancient story, although it shown most contents with the style of American culture, which is the defect. Furthermore, Kung Fu Panda got a bigger success with Chinese characters and the style of Chinese culture. The movie had attracted Chinese children and parents with its cultural elements and funny story. We had to respect the animated movie with 100 million RMB at the box office.

American animated film got good consensus of Chinese audience with humor, grand scale, fast pace. Last year, Mr. Peabody And Sherman, and Turbo win the children and parents' heart by its cute childish psychology and childhood story.

\section{Introduction: Common Theme of Growing UP}

\subsection{Take an Example of the Movie Mr. Peabody \& Sherman}

Mr. Peabody \& Sherman is a 3D computer animated science fiction film (Peabody \& Sherman, 2013, 2014). The characters in the film come from the American animated serials" The Rocky and Bullwinkle Show" (Peabody \& Sherman, 2014) in 1960s. The story talks about Peabody, the best smart dog in the world, who adopt a boy called Sherman, and start a fun journal.

Peabody invented a time travel machine for his son to explore the fantastic world. They traveled the time space, adventured the entire world with great happiness. Mr. Peabody abandoned Sherman to adventure by himself, and tries to make a totally safe and beautiful world. Sherman like it which Peabody given, too. But Sherman and his classmate Penny Peterson's Bite Issue broke the peace. Peabody was been doubt by Child Protective Services whether been suitable for raising Sherman any more, which disturb his mind deeply.

In order to clear the misunderstanding, Peabody invited Penny, the classmate of Sherman and her parents. Sherman told the secret of the time machine by mistake, and travelled with her through the time in which like Trojan War, Renaissance Italia, Ancient Egypt, finished dangerous and interesting trip. In the trip, Sherman found his independent exploration courage. However, Sherman, Penny came back to the time when there is a himself before since he need to rescue his father. This mistake made the time machine broken. Finally, Sherman found the way entering to the future time space and fixed the time machine. After the accident, Peabody found the right way to raise a brave and independence son, and Penny has been good friends with Sherman. 


\subsection{The Attraction of Mr. Peabody \& Sherman}

Like the Ender's Game shown recently, Mr. Peabody \& Sherman respects the mind and the energy of children. They endow the Children nature intelligence, and the nature which the adults lack: the Courage of Exploring, Flexible Thinking, Persistence and cooperating spirit. In the movie, time machine accident made Peabody understand the importance of respecting the mind of children. At the end of the movie, Peabody said: "Every doggy need a boy." Children and animals' equal rights were approved and respected totally in the movie, which was welcomed by children audiences. Because Children eager the freedom flying and exploring in the strange world, and making the dreams coming true.

\subsection{The Subject of "Growing Up"}

The theme of Growing Up can answer the criticism. Postcolonial scholars Michel Foucault thought that word's knowledge deeply are results of discourse right contest. So there is criticism that American movies show deep individual heroism, occupying public discourse space of International Film. For example, Turbo and Kung Fu Panda all include the action that hero rescued the world or put things right. However, these movies have not exceeded the spirit of Growing Up. The heroes in the movies had been becoming strong from weak, like we did in growing up, which comfort children audiences.

Although not every movie contains a "Happy Ending", but the subject "Growing Up and Hope" is always the Public Discourse of Children Movie. For example, Snow White and the Seven Dwarfs, The Monkey King, Spirited Away and so on. Some movies with strict subject, like The Red Balloon, which is representative of Iranian movie.

The movie The Red Balloon tells us a story about a little boy. In the movie, a few sentences of characters, black and white frames, lonely road, the ill-tempered headmaster of the primary school, the strict guardian, the elder boys who liked picking on the hero of the movie. The description of background and the characters develops Stress and depression moods. On the other hand, the red balloon and the little hero, who helping, loving and keeping together with each other, make the story calm and warm. The plot that the elder boys pursued and attacked the balloon, and the hero rescuing it, makes the movies go to the climax. With a pity, the balloon has finally been broken, when dying and attacked by a stepping on. The plot makes the audiences move with the sadness of the hero. At this moment, many colorful balloons came from everywhere, the hourses, the streets, the hands of other children. The little hero found laugh on his face, flied with balloon far away. The Red Balloon makes little audiences feel lonely and helpless, warm and happiness, at the same time, makes the adults audiences could found impotence and optimism to lives. Above all, no matter the adult s and the children could all found the shadows of their own.

Just like the argument in the book Animated Film Analysis (Habermas, 1999), which say that, the adults and the children like to see the movies with subjects of Growing Up, in which heroes got to be successful by hard working, or like to found the similar circumstances with the heroes in the movies, who keep company with the audiences. Furthermore, they like to study to keep peaceful to face the success and failure in the lives like the hero does in the movies, and find the hope and courage. This is the Mind soothe function of animated films. The children's faculty of understanding is limited, simple, sensitive and rich. They would like to see the happy ending, and enjoy fun and warm.

\section{The Contents of the Movie: The Spots of History and Culture in Humor Ways}

Some American animated films absorb nutrition from the civilization in the world, and make it sophisticated for the movies. Besides, they show audiences visual feasts with montages. Take Peabody and Sherman for example, Mr. Peabody play the Rhapsody in Blue and many history stories in humor ways as follows.

\subsection{The History Events or Culture}

Table 1 . The history events

\begin{tabular}{llll}
\hline NO. & The history events & NO. & The history events \\
\hline 1 & the painting Washington Crossing the Delaware & 8 & Anubis \\
2 & Franklin flied a kite for lightning & 9 & Moses from the movie The Prince of Egypt \\
3 & The painting A Starry Sky of Van Gogh & 10 & Mohandas Gandhi sat on a blanket in india \\
4 & Wright brothers invented the planes & 11 & Achellolles' knees \\
5 & Peabody played kazak Dombra & 12 & Oedipus \\
6 & Egyptian pharaoh & 13 & Odysseus in The Odyssey which comes from Homer's Epic \\
7 & Egyptian pharaoh Tutankhamun & 14 & Robespierre in The French Revolution \\
\hline
\end{tabular}


In the class, Sherman talk about the first president Washington crossed over the Delaware river, which comes from the painting Washington Crossing the Delaware. The story of Washington and the cherry tree had been the blasting fuse of the quarrel of between Sherman and Penny, which is the start of the story. We can find the events in the table 1.

\subsection{History in Humor Ways}

Take a case for example. Peabody and Sherry take the time machine through French Revolution, Queen Marie and the Cake story comes from another famous story. It is been said that when the minister told Marie Antoinette of Louis the sixteenth the civilians had no bread, Marie said strangely: Why don't they eat cake?" Then the civilians revolted. But the truth belongs to the queen of Louis the fifteenth.

Besides above, there are many history stories include in the movies in smart humor ways. We can find them in follow table.

Table 2. History stories in humor ways

\begin{tabular}{llll}
\hline NO. & Event & NO. & Event \\
\hline 1 & Queen Marie and cakes & 5 & Trojan horse \\
2 & Shakespeare's signature & 6 & Clinton's mistake(indicating Lewinsky) \\
3 & Mona Lisa Smiles with the fun of Peabody & 7 & Da Vinci produces Pop Arts and graffiti by Mona Lisa \\
4 & Da Vinci wooden aircraft & 8 & Agamemnon who loves war and grumpy Miss Merit \\
\hline
\end{tabular}

At the end of the movie, Beethoven was playing dancing machine, Einstein played magic square and lose, Newton took the apple, Confucius flashed when the time machine fixed and absorbed the history characters back into the machine.

Above all, many spots in the Peabody and Sherman shows humor style and affluent contents with exquisite culture spots. Animated movie, which is included in cultural creative industry, needs abundant culture elements, and creative ways to combine them together for movie theme, which is superiority in markets competition.

\section{Characteristic of Translating American Animated Movies into Chinese}

Take Peabody and Sherman and Turbo for example, we can find the interesting things.

\subsection{The Name of a Movie}

Peabody and Sherman have been translated into "The Genius Dog", and Turbo has been translated into "The fastest Snail". The two movies had been named by the characters' names, and, in truth, there is few American movies translated into Chinese in the same way with itself language.

Movie is based on moving images, which is different from painting and sculpture, and hard to show the choice for people to select the spot to view. The name, which is the first shot of a movie shown to audience, is very important in guiding since above reason.

There are a few ways to name the movies in China, which is tightly connected with their cognitive style. The ways can be collected as follows. (Zhou, 2007)

\subsubsection{Category and Prototype}

It means named movies by the name of the characters, the time, the events, the subjects in the movie. For example, Zhou Enlai (1992) named by the name of the character, audiences can understand that the movie will tells us a story about Zhou immediately. As the same way, we can easily clear that they talk about the love in Love in a Fallen City (2009) and Hot Summer Days (2010).

\subsubsection{Metaphor or Simile}

Take in the Mood for Love (2000) for example. The name of the movie has not shown the theme, but keeps audience curious. Flying Swords of Dragon Gate (2010) and The Flowers of War (2011), the names of which use the characters of the heroes, make the atmosphere mysterious.

\subsubsection{Familiar and Fun}

In the Handphone and Eat Hot Tofu Slowly, the names of the title is familiar for audience as daily supply and everyday life language, which can be warm and self-identified, keeps audience at arm's length. 
The style of the names which translated from the American animated movies is a combinations of the first and the third on the above. For example, "The Genius Dog" and "The fastest Snail" make parents understand they are stories about a good dog and snail immediately, and the characters of them. The dog and snail are familiar and interesting for children, and there are big differences between the characters in movies from in truth, since that genius for a dog and high speed for a snail are incredible.

In a word, a good name which suitable for people in native markets is important for attracting the audiences.

\subsection{Cultural Integration}

In the translating course of American animation films, cultural integration is the key to solve communications problems when the movies enter Chinese market. As the reason, it influences Chinese audiences' acceptance and interest, as same as whether the Public Discourses installed suitable, the humor fun, or Chinese culture elements combined dexterously for American movies. On the other hand, Crazy Stone (2006), which had been sweeping the country, ran up against a stone wall when exported. The audience in other countries can't accept the humor and understand the life style in China, so the movie lost the attraction.

\section{Discussion}

\subsection{The Internationalization and localization: American movies' Public Discourses in China}

\subsubsection{The Construction of Public Discourses with Movies}

American animated movies are expanding in China. Jun Liu (Lin, 2012) thinks of movies as Public Discourse. Although he confused them, but showing the value of movies in constructing the Public Discourse. The communication of movies installed complex Public Discourse, which related tightly with political movements, business capital, and culture. Above all, we have to admit that the Public Discourse is not only a single discourse, but also a complex of Culture Creation, Ideology, Capital for Trading Purpose, and the Public Rights. At the same time, the construction of Public Discourse pushing on the movie communication.

\subsubsection{The Reason of acceptation of American Movies}

American movie are acceptable by other countries, because it is acceptable by the Public Discourses of them. Disney, Pixar, as the famous American animation companies, created the animated movies giving the feeling like: visual feast, funny Gags, suiting both refined and popular taste, fit for all ages. The box offices of American animated movies is higher than Chinese (Wang, 2013), the results of that the movies of American has been acceptable by the audience, entering the public discourses with style of themselves. Chinese audiences like the large production, beautiful design, vivid story, tense rhythm and fun. Andre Maurois said: "Screen not only cultivates the audience's understanding of Art, but also cultivate their understanding of life itself." The success of American animated films in Chinese means not only the narrative style of movies be acceptable, but also the views points and habits of the movie writer winning supports of the audiences. As Lingli Wang (Zhou, 2007) said: "The movie can win the preemption when entering the international movie market, if it wins the power in Public Discourse."

\subsection{How about Chinese Animated Films?}

Chinese animated films aim to be interested by the world, with its own style and story. They got some success (Wang, 2013), like The Monkey King (1964) with Beijing opera style, and Where is Mama (1961) with Chinese Painting. Besides, all the aims need not only the efforts of animation companies themselves, but also political, business and culture communication organizations' efforts. Business Capital operation and Culture Communications, like devil and angel, are accompanying with animated films. The Chinese animated films need humor points and stories in business ways to fulfill the audiences' sensory stimuli. At the same time, Chinese animated films need absorbing varied cultural achievements from other countries, in order to make the styles and story themselves acceptable by audiences in various countries.

\section{References}

Habermas, J. (1999). BurgerlicheOffentlichkeit (trans. Weidong Cao, 1st ed.). Academia Press.

$\mathrm{Hu}, \mathrm{X}$. (2014). Chinese animation comes back to the Public Discourse. Asian social science.

Lin, N. (2012). The names of Chinese movies in cognitive linguistics views. Film Literature.

Liu, J. (2011). Whose Public Discourse? Chinese films and the construction Public Discourse.

Mao, Q. (2008). Philosophy study of Contemporary movies. The University of Overseas Chinese.

Peabody, \& Sherman. $(2013,2014)$. The cute father and son travel through the time machine [DB/OL]. 
Peabody, \& Sherman. (2014). Mtime.com.

Wang, L. (2013). Ideology expression in Animated Films-take American adapted animated films for examples. News Communication.

Zhou, J. (2007). Animation films analysis (1st ed.). JiNan University Press.

Zhou, J. (2007). The analysis of Animated Movies. University of International Business and Economics Press.

\section{Copyrights}

Copyright for this article is retained by the author(s), with first publication rights granted to the journal.

This is an open-access article distributed under the terms and conditions of the Creative Commons Attribution license (http://creativecommons.org/licenses/by/3.0/). 